\title{
Peasants of Tropical Africa Face the Challenges of Agricultural Produce Markets (Case Study of the Self-Managed Market of Cotton in Chad)
}

\author{
NDOUTORLENGAR Médard ${ }^{1}$, TAMTIAL Ngariban¹, DAOUYA \\ Philémon 1
}

${ }^{1}$ Department of geography, University of Sarh, Chad

\begin{abstract}
Many African countries are famous suppliers of the agricultural produce consumed throughout the world. But they are far to control the markets of these products most often established and decided out of the continent (HARSAH E al, 1994). It results from this a dysfunction to the system of production felt as well by the companies than the producers. Such is the case of Chad through the production of cotton where the difficulties of company COTONTCHAD involve socio-economic changes in the producing rural areas of cotton. On the basis of investigations, interrogations and direct observations, this article makes an analyze of new self-managed market to understand the difficulties of the producers in the context of this market. The establishment of producers typologies permitted to apprehend, according to geographical space and of categories of the producers, the changes generated by the cotton crisis.
\end{abstract}

Keywords: Chad, Cotton-Peasant-Market-self-managed

\section{INTRODUCTION}

Tropical Africa is one of the providers zones of many agricultural produce consumed throughout the world. It acts, inter alia, of the cocoa, the coffee, the hévéa, arabic gum and cotton. This last constitutes the principal generating activity of the incomes of 33 African countries peasants (COUSIN P., 1993) of which the Franc Zone such as Benin, Burkina Faso, Cameroon, Ivory Coast, Mali, Niger, Central African Republic, Senegal, Chad and Togo (Braud M., 1990). But the market and the transformation of the majority of these various products are done outside the continent. This externalization is very often source of the difficulties for the companies and the producers peasants. The characters of these difficulties differ from a country to another according to local contexts.

Chad is producing and commercializing cotton and arabic gum. But cotton is the product whose commercializing system most often encounters difficulties so hard involving sometimes situations to which the responsible company and the peasants producing face with difficulties. (GUI A., 1996; NAYGOTIMTI B, 1997). The dysfunction of cotton sector is often related as well as to external and internal parameters. To world levels of cotton fluctuations and the subsidies given by the rich countries to their producers (GOUREUX L, 2003;AMEDE L, 2002;TOURE A. T., 2004;WISE $\mathrm{T}$ A., 2004) common runs to all the producer countries, are added the continentally of the country which imposes to the responsible company of cotton enormous expenditure and risks to lead the product to the international market (MAGRIN G 2002), the climatic risks having for consequences the random outputs (MAHAMAT DJIMADINGAR et al., 2011), the financial embezzlements and laxism which cause, per year, enormous deficits to company (CHRETOM B, 2000).

Cotton sector difficulties generated many changes in several scales into Chad. Into the national scale, the cotton culture is reduced, since 1984, to zones of high productivity followed by the closing of the 15 factories of cotton shellings on 24 created (cf. figure $n^{\circ} 1$ ).

Figure $n^{\circ} 1$ : contracting zone of production in Chad cotton

This article is published under the terms of the Creative Commons Attribution License 4.0

Author(s) retain the copyright of this article. Publication rights with Alkhaer Publications.

Published at: http://www.ijsciences.com/pub/issue/2015-07/

Article Number: V4201507764; Online ISSN: 2305-3925; Print ISSN: 2410-4477 


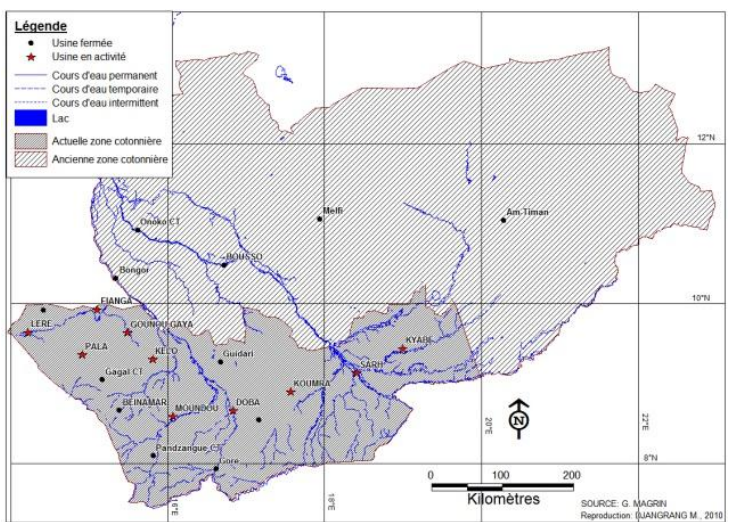

Into the company scale, the personnel compression is one of the first consequences of the cotton sector difficulties. Follow after the removal of the traditional market to the "self-managed market" and the regrouping of the producers under Village Associations (VA).

Into the village scale, the peasant's reactions face the changes of the responsible company of cotton vary from a zone to another according to the financial margins of the producers and geographical constraints (REOUNODJI F, 2002). They go from diversification of the agricultural productions to the avoidance for the interior zones and the transfer of market for the others of the border areas to Cameroun Republic.

\section{METHOD AND MATERIALS}

Investigations and direct observations are the principal research orientations of which the data, coupled with work of other author which preceded us on the set of themes, made it possible to carry out this article.

The investigations were carried out near the producers of cotton on the one hand and other, of the agents of the responsible company of the product.

In the first case, the target is made up as well of the cotton producers isolated as those members from Village Associations. The aim had near this target is to understand the effects produced by the new mechanism of marketing of cotton and the degree of country adhesion to this new mechanism of the market and the production of cotton in the context of the crisis which lasts. On the whole $26 \mathrm{VA}$ are visited and 300 surveyed people is 260 members of the AV and 40 independent producers distributed in 3 areas as follow:
Table 1: Distribution of the inquired people according to areas

\begin{tabular}{|l|c|c|c|}
\hline Region & VA & $\begin{array}{c}\text { Member } \\
\text { s }\end{array}$ & Not members \\
\hline Logone Oc & 12 & 100 & 15 \\
\hline Logone Or & 10 & 95 & 15 \\
\hline Tandjilé & 4 & 65 & 10 \\
\hline & 26 & 260 & 40 \\
\hline
\end{tabular}

Source: Our investigations, 2014

Beside the factories of the responsible company of cotton, the step consisted in apprehending the mechanism of operation of the new system of marketing.

The site of research covers 3 administrative areas belonging to the soudanien climatic zone where agriculture is the principal activity of the populations with strong density and rural majority. It is about the area of Logone Occidental through the departments of the Lake Wey and of Dodjé, of the area of Logone Oriental where we made the investigations in the departments of Pendé and Mont de Lam. In the area of Tandjilé, we worked the departments of Donon Manga and Béré.

The objective sought through the extension of the investigations to the three various administrative areas is to understand the character of the situation in each one of them and the types of the strategies adopted by the producers to face the encountered difficulties.

According to the types of strategies adopted by the producers and their degree of adhesion to the culture of cotton, we have ourselves established a typology of the productions and actors country.

\section{RESULTS AND COMMENTS}

The introduction of the new market did not give to all the scales anticipated results. If the level of the responsible company of cotton the self-managed market made it possible to protect the interests, in the mediums of the producers, it presents sometimes insufficiencies and disadvantages which led to the discouragement of the producers.

\subsection{The Self-managed Market: a} protectionist measurement of the company

The Self-managed market is a primary form of cotton marketing imposed by the responsible company of the product to the peasants. It consists in entrusting to the peasants the organization by themselves, the quality control, the loading of the cases and the payment (MBAIHOUNDAM, 2001).It is applied to double objective. The first, in the interest of the COTONTCHAD, is that to reduce the cost of purchase of the cotton which the company engaged 
and risks incurred in the old system of the primary cotton market. Indeed, in the old system, the agents purchasing of cotton moved from village to village with money cases and operations for long stays. The encountered problems were, inter alia, the assumption of responsibility of the team of purchase of cotton, the steerings with hands armed with the procession and the diversions by certain purchasing agents which cross the borders with the money intended to pay cotton with the producers. The starting of the new system of market of cotton systematically involved the removal of labour for handling during the campaigns and mission the expenses of the paying agents. It results from it a saving weight wage and all expenditure from the various operations.

In the interest of the producing peasants, the hard aim is the concern of reducing the sordid exploitations of the purchasing agents and the interposed people (BONNASSIEUX A., 2002).It was very current to note, with weighing, a difference between the real quantity of $\mathrm{kg}$ of cotton communicated to the producer and that recorded by the purchasing agents. Also the organization of purchase of cotton called it spontaneous markets where the tradesmen made higher bid.

Thus, the Managed Self-managed Market is distinguished from the traditional market of cotton by:

- The regrouping of the peasants under a Village Association which is the only condition to be able to profit from seeds, loans of the plant health products provided according to the need for Village Association (cf. table $n^{\circ} 2$ ) and to have access to the market. Even if the seeds are offered free by the company, they are given only to the members of village associations.

Table 2 : expenditure by year crop according to needs of VA

\begin{tabular}{|l|c|c|}
\hline Designation & Unit price & Needs of VA \\
\hline Seed & - & - \\
\hline Manure & 14.000 & $\mathrm{X}_{1} \times 14.000$ \\
\hline $\begin{array}{l}\text { Plant health } \\
\text { treatment }\end{array}$ & 850 & $\mathrm{X}_{1} \times 850$ \\
\hline Total & 14.850 & $\mathrm{X}_{1} \times(14.850)$ \\
\hline
\end{tabular}

Source: Moundou COTONTCHAD direction, 2013

$\mathrm{X}_{1}$ represents the number of hectares likely to be sowed expressed by applicant Village Association.

- The organization of the market of cotton from the village to the factory of cotton shelling by the producers the team of purchase is in general made up of 9 peasants. It consists of a president, two secretaries and two conveyors. The technical team contains two weighing and two pointers;
- The rebate which is not other than the counterpart of the provision of services provided by the peasants poured by company COTONTCHAD. To that is added the expenses of loading calculated on delivered tonnage (cf. table $\mathrm{n} 3$ ).

Table 3 : Calculation system into self managed market

\begin{tabular}{|l|l|l|}
\hline Designation & \multicolumn{1}{|c|}{ Value } & \multicolumn{1}{|c|}{ Calculation system } \\
\hline $\begin{array}{l}\text { Expenses of } \\
\text { loading }\end{array}$ & $0,8 \mathrm{f} / \mathrm{kg}$ & $\mathrm{X}_{2} \mathrm{~kg} \times 0,8 \mathrm{f} / \mathrm{kg}$ \\
\hline ''Ristourne'" & $2,8 \mathrm{f} / \mathrm{kg}$ & $\mathrm{X}_{2} \mathrm{~kg} \times 2,8 \mathrm{f} / \mathrm{kg}$ \\
\hline $\begin{array}{l}\text { Net income } \\
\text { of cotton }\end{array}$ & $215 \mathrm{f} / \mathrm{kg}$ & $\mathrm{X}_{2} \mathrm{~kg} \times 215 \mathrm{f} / \mathrm{kg}$ \\
\hline Total & & $\begin{array}{l}\mathrm{X}_{2} \quad \mathrm{~kg} \\
(0,28+2,8+240)\end{array}$ \\
\hline
\end{tabular}

Source : COTONTCHAD of Doba, 2014

$\mathrm{X}_{2}$ is the quantity of $\mathrm{kg}$ presented by village association at the factory of the COTONTCHAD

These values are applied to the rough weight of the cotton led to the factory. The expenses of loading, calculated on arrival of the cases to the COTONTCHAD, are immediately given to the conveyors. On the other hand, the incomes Nets of cotton and the rebates are paid according to the availability of the financial plate of the company. The latency of the incomes of cotton goes sometimes until a year.

- The joint guarantee. It is a method of covering of the expenditure of the crop years according to which Village Association is the only legal entity that the company recognizes. The refunding of the expenditure of the crop year is made at the source with the payment of the cotton money on the mass of Village Association whatever the output. In case of deficit, the company did not consider the individual member of Village Association in situation of deficit. It deducts simply the expenditure of the countryside on the mass of the incomes of the cotton of the whole of the members.

- Downgrading of cotton. The cotton led to the factory by the peasants is appreciated and classified in three categories called choice from which the prices with $\mathrm{kg}$ differ. The criterion of appreciation is the cleanliness of cotton. Thus, one distinguishes cotton from first choice whose price with $\mathrm{kg}$ for the marketing year 2013-2014, out of F CFA of Central Africa, is 240 while that of the second choice is worth 156 with $\mathrm{kg}$. The price of the cotton of the third choice is of $102 \mathrm{f} / \mathrm{kg}$.

\subsection{Self-managed marked difficulties}

As any human work, the self-managed system of the cotton market presents some advantages and 
disadvantages. The latter are felt in the areas of the producers and the responsible company of cotton. By its devices, it constitutes for the peasants a gangrene for the rural economy and is sometimes at the origin of the many conflicts intra-association in the village communities It results from this the strategies of fight whose characters depend on the producers capacities.

\subsubsection{The delays make random the cotton incomes}

The primary education system of marketing of cotton in the villages consists so that the company, after harvest, places at the disposal of the producers covers to organize by themselves weighing and of the cases for the evacuation of cotton granulates. But because of the recurring financial difficulties, the COTONTCHAD is often unable to provide to real time the tools necessary for organization of the market. The organization of the market starts in general in February. With the result that certain villages make the market at the time when a new crop year starts. It is the case of the village of Mokloh Kembeut and Miré Tchindé in Tandjilé in 2012. The other illustrative examples are Bessèmè in Logone Oriental and Sawa in Logone Occidental respectively in 2012 and 2103.

If the delay in the organization of the market is related to the difficulties which the company encounters, that of the refunding of the incomes of cotton to the producers is inherent in the new system. After organization of the market, the representatives of the producers escort the cases to the factory where they perceive the expenses of loading. The incomes Nets of cotton and the rebate are paid later with the convocation by the company. It occurs, in general, between two to three months of the date of the entry of the product to the factory and the refunding of its income. It follows that the producers of certain villages having organized with delay the market perceive the incomes of cotton to the harvest of the products of the following countryside.

\subsubsection{Joint and several guarantees}

Effective mechanism of covering of the expenditure of the crop years imposed by company COTONTCHAD, the joint and several guarantees have affected, at least once, each Village Association of the three areas where we carried out the investigations. On the whole 9 visited associations out of $26 \mathrm{knew}$ the misdeeds of the joint and several guarantee for crop year 2012-2013 with a deficit of 1041950 F CFA and touched 46 people members of associations. The incomes of the cotton of the marketing year 2013-2014 are not yet known at the date of our investigations.
Table 4: Distribution of VA victims into joint several guarantee by area and amount.

\begin{tabular}{|c|c|c|c|}
\hline Region & VA & Deficit & $\begin{array}{c}\text { Concerned } \\
\text { members }\end{array}$ \\
\hline $\begin{array}{c}\text { Logone } \\
\text { Oc. }\end{array}$ & $5 / 12$ & 512850 & 19 \\
\hline $\begin{array}{c}\text { Logone } \\
\text { Or. }\end{array}$ & $2 / 10$ & 320600 & 15 \\
\hline Tandjilé & $2 / 4$ & 208500 & 12 \\
\hline & $9 / 26$ & 1041950 & 46 \\
\hline
\end{tabular}

Source : Visited VA, 2014.

The joint and several guarantees are regularly ascribable with the deficits of the agricultural outputs. The causes of those are numerous. In addition to the poverty of the grounds common to all the areas, the principal causes of the deficits are, by places, the climatic risks and none use of the plant health intrants and produced. With these causes the downgrading of cotton is added. Indeed, the pluviometric deficit and/or a strong late rainfall and the bad conservation by the producers exploit the quality of cotton leading to the downgrading. Certain members of the VA divert the manures and the health plant products provided by company to use it for other cultures with the detriment of the cotton for which they are granted. It results a weakness of output.

\subsubsection{Diversions of the incomes of cotton and the rebates}

The system according to which they are only the representatives of each Village Association having sold cotton which will perceive the mass of incomes of this one does not put at the shelter the new market of the steerings and diversions. But contrary to the first market, in this case, the losses are recorded only by the peasants.

If the steerings with armed hands are caused by the hijackers, the authors of diversions are not foreign with village Associations. After having perceived the cotton incomes of association, some deputies cross simply the borders of the country with the hope of a whole village. One of the examples illustrative is that of the VA of the village of Bémouleu where two delegated VA accomplices disappeared with more than three million which represents the annual incomes of the peasants.

The other form of diversion takes place in the management of rebates (BAIDOU R., 1993).20/26 visited associations knew at least once the financial embezzlement. But only 5 of the 20 have recovered the money. These financial blunders are often caused by the absence of the legal bases and the reports/ratios of the mandates of the committees directories of associations. 7/26 of the VA visited 
hold a statute and rules of procedure duly written which govern them. 8/26 held an annual report regularly.

\subsubsection{Downgradings}

The downgrading of cotton in the factories of shelling is recurring per year and countryside. The quantities of displaced cotton vary according to the degree of clogging of the product leading to the type of choice which the company imposes to him (Cf. table $\left.n^{\circ} 5\right)$.

Table 5 Distribution of the bought cotton quantitities according to choices' in Western Logone and in East Tandjilé

\begin{tabular}{|l|l|c|}
\hline Catégory & Quantity & Percentage \\
\hline Choice I & 15853015 & 98,00 \\
\hline Choice II & 107480 & 0,66 \\
\hline Choice II & 214965 & 1,34 \\
\hline Total & 16175460 & 100 \\
\hline
\end{tabular}

Source : COTONTCHAD of Moundou, 2014

The factors which contribute to the downgrading of cotton are numerous. They can be classified in two categories. A first comes from the country organization sometimes related to poverty, sometimes with the negligence or the lack of knowhow. One second category is related to the delay of purchase of the cotton of to the financial difficulties recurring known by company COTONTCHAD.

Indeed, after harvest, the conservation of the product leaves something to be desired. In the fields, while waiting for the evacuation, the product is placed at bare ground and open sky without any protection. With this phase, products boxes the remains of the sheets and the brandilles as well as precipitations of all kinds. In the villages, after evacuation, the product always placed on the bare ground, is used sometimes as bed or place of play of predilection of children.

The second phase of clogging of the product is in the mechanism of marketing in the Centers of Purchase (CP) assembled by village associations. The centers of purchase for all visited associations are held under the large trees of the public places. The device of weighing consists of two vertically planted forks on which a branch of tree is placed horizontally. With the latter is hung a mechanical balance (Cf. figure $\mathrm{n}^{\circ} 2$ ).
Figure 2: An example of purchase center of cotton



The Center of purchase are in général dirty..

(Cliché : Ndoutorlengar Médard, 2014)

The various requirements of the new system of marketing of cotton and the risks of the incomes of the product operated many changes in the rural mediums. They also led the producers gradually to adopt strategies according to their average materials and financial to face these changes.

\subsection{Country changes and strategies}

To face the various changes the need for developing strategies is essential. Those differ according to whether the producers of cotton are inside the country or the border area of Cameroun, close country.

\subsubsection{Relaxation of the cotton production inside the country}

At the interior of the country three categories of the producers emerge with strategies which differ according to the margin capacities of the ones and others.

\section{- Producers of category I}

Accounting for $42,28 \%$ of our sample and having for principal objective food self-sufficiency for reasons of the precariousness of their means, their strategy is directed towards the abandonment of the cotton production $\left(\right.$ Table $n^{\circ} 6$ ). 
Table 6: Production strategies of the exploitations of category I

\begin{tabular}{|c|c|c|}
\hline Objective & $\begin{array}{l}\text { Marked } \\
\text { strategies }\end{array}$ & $\begin{array}{l}\text { Marginal } \\
\text { strategies }\end{array}$ \\
\hline $\begin{array}{l}\text { Food } \\
\text { autosubsistance }\end{array}$ & $\begin{array}{l}\text { - cereal } \\
\text { production; } \\
\text { - groundnut } \\
\text { production of; } \\
\text { - sesame } \\
\text { production }\end{array}$ & $\begin{array}{l}\text { - Abandonment } \\
\text { of cotton culture }\end{array}$ \\
\hline $\begin{array}{l}\text { Increasing } \\
\text { incomes }\end{array}$ & $\begin{array}{l}\text { - Labour paid in } \\
\text { the fields of the } \\
\text { two other types }\end{array}$ & $\begin{array}{l}\text { Gathering of nuts } \\
\text { of shea tree; } \\
\text { clothes industry } \\
\text { of the plaits and } \\
\text { the baskets; } \\
\text { - Rural migration }\end{array}$ \\
\hline
\end{tabular}

Source : Our investigations, 2014

The priorized cultures in the agricultural productions are primarily the groundnut $(45 \%)$ and me sesame $(25 \%)$.

\section{Producers of categories II}

Their principal activities agriculture (80\%), the trade $(10 \%)$ and the breeding $(9 \%)$ which aims to the increase in the incomes (cf Table n6). They account for $47,12 \%$ of our sample

Table 7: Production strategies of the exploitations of category II

\begin{tabular}{|c|c|c|}
\hline Objective & $\begin{array}{l}\text { Marked } \\
\text { stratégies }\end{array}$ & $\begin{array}{l}\text { marginal } \\
\text { Stratégies }\end{array}$ \\
\hline $\begin{array}{l}\text { Food } \\
\text { autosubsistance }\end{array}$ & $\begin{array}{l}\text { - cereal } \\
\text { production; } \\
\text { - groundnut } \\
\text { production of; } \\
\text { - sesame } \\
\text { production }\end{array}$ & $\begin{array}{l}\text { - Peaking, } \\
\text { Hunting et } \\
\text { Fishing. }\end{array}$ \\
\hline $\begin{array}{l}\text { Increasing } \\
\text { incomes }\end{array}$ & $\begin{array}{ll}- & \text { cotton } \\
\text { production } & \\
\text { - Breeding } & \\
\text { - Trade }\end{array}$ & $\begin{array}{l}\text { Agricultural } \\
\text { credits }\end{array}$ \\
\hline
\end{tabular}

Source : Our investigations, 2014

With the average consequent materials being able to allow them to support the delay of the responsible company of cotton, these producers adopt a defensive strategy of diversification by producing cotton $(16 \%)$, groundnut $(51 \%)$ and sesame $(24 \%)$. The marginal productions account for $9 \%$.

\section{- $\quad$ Producers of category III}

This category is primarily made up of the administrative and military authorities, the tradesmen and other civils servant such as the teachers, the agents of the ministry of agriculture, of breeding and some members of the personnel of the NGO of rural development which operate in the zone. Agriculture constitutes for it a source of increase in the incomes. It accounts for $10,60 \%$ of the sample of our investigation.

Table 8: Production strategies of the exploitations of category III

\begin{tabular}{|l|l|l|}
\hline Objective & $\begin{array}{l}\text { Marked } \\
\text { stratégies }\end{array}$ & marginal Stratégies \\
\hline $\begin{array}{l}\text { Food } \\
\text { autosubsistanc } \\
\text { e }\end{array}$ & $\begin{array}{l}\text { Professionna } \\
\text { occupations. }\end{array}$ & $\begin{array}{l}\text { Commercial activities } \\
\text { - Agricultural } \\
\text { diversification. }\end{array}$ \\
\hline $\begin{array}{l}\text { Increasing } \\
\text { incomes }\end{array}$ & $\begin{array}{l}\text { - groundnut } \\
\text { production; } \\
\text { - cotton } \\
\text { production; } \\
\text { - Use of the } \\
\text { labour }\end{array}$ & $\begin{array}{l}\text { - Commercial } \\
\text { - Orchard; }\end{array}$ \\
- Breeding.
\end{tabular}

Source : nos enquêtes, 2014

The occupations occupy in majority their productions (50\%).Agriculture comes in second position $(25 \%)$. The trade and the breeding come in second and third position with respectively 12 and $9 \%$ their productions. $4 \%$ are devoted to the marginal ones. Their strategy is offensive.

\subsubsection{The cotton of the border areas}

From their geographical position, the Chadian producers of the cotton of the border areas of Cameroun are relative with the shelter of the constraints of the self-managed market and the misdeeds of the delay in the purchase of cotton. Indeed, if from the side of Chad obtaining the seeds and products plant health is related to the membership of the applicant to a village association, in Cameroon it is not question. The purchase of the product is not related to any constraint. Then, this type of producers adopts a strategy different from that of the interior zones.

Thus, to have the seeds and the plant health products, it is enough to cross the borders to go to the weekly markets Cameroonian villages. Cameroonians bring sometimes in the local markets articles. The borders are porous. Also one does not find the same people on each side of the border? It is the case of the ethnos groups Moundang, Toupouri, Mboum... ethnics groups.

This freedom of access to the seeds and the health plant products gives a possibility of choice to these types of producers. It results from this that one meets in these zones more of the independent 
producers that those gathered under village associations. In this manner, to the cases of delay of purchase and fall of the purchase price of cotton, by the COTONTCHAD, the producers of the borders cross to sell cotton in Cameroon in the field of the SODECOTON which is the company in charge of cotton in Cameroon.

This type of the producers are at the same time in Western Logone, Eastern Logone and Western Mayo Kebbi. In the area of Western Logone the zones concerned are Goumadji, Beinamar and Manda Kouti. In Eastern Logone, they are the zones such as Baïbokoum, CAM, Larmanaye and Lombogo. Some villages of Léré and Fianga are concerned in the area of Western Mayo Kebbi.

\section{CONCLUSION}

The instability of the world levels of cotton and subsidies made by the rich countries with their producers on the one hand and of the difficulties related to the continentality and the problems of internal management in relation to the instability of the country lead to length of the decades a dysfunction in the company in charge of cotton. To deal with these difficulties the decision makers adopted a protectionist strategy of the interests of the company. This one consisted in changing the system of cotton market whose objective is to reduce upstream to the maximum possible the loads of the company like downstream in cotton years crop.

The changes operated in company CONTONTCCHAD have, by rebound, also generated changes in the producing rural mediums of cotton in Chad. The changes are such as only the peasants who have the average materials and financial draw profile and the situation from stripped the enlise. To face these socio-economic difficulties, the strategies are developed according to the means and of geographical spaces. With end of the one decade patience of difficulty, in the rural mediums the discouragement settles gradually. That led to the abandonment of the production of cotton to the profit of the other cultures whose marketing is not related to any constraint.

\section{REFERENCES BIBLIOGRAPHIQUES}

[1] HARSAH, E. ; OULEYMAN A. ; KALOUBRY A.; BELLMARE M.; 1994: l'Afrique face aux marchés mondiaux: GATT, la plupart gagnent, l'Afrique perd. L'Afrique peut-elle vraiment diversifier sa production agricole? Les agriculteurs ivoiriens se lancent, les producteurs burkinabé passent à l'action et les nigériens contre l'ajustement. Agriculteur africain n¹1, 1994/04 P.15-42

[2] COUSINE P., 1993, la situation mondiale du coton et le cas de l'Afrique «zone franc» CIRAD-CA, Laboratoire d'économie. Communication atelier. UCAD-CIRAD à San José, Costa Rica, 12p. Et annexes 21p.

[3] [1] BRAUD M., 1990, «La filière coton en Afrique de l'ouest et du centre : un pôle de progrès dans un océan de morosité », note CIRAD/IRCT, 30p

[4] AGUI A., 1996: La culture du coton tue à petit feu le paysan tchadien. La voix du paysan $n^{\circ}, 22$ p. Ndjaména.

[5] NAYGOTOUMTI M.B., $1997: 25$ ans de Coton au Tchad. Un non-événement. Tchad et Culture ${ }^{\circ} 156,6-7 \mathrm{pp}$.

[6] GOUREUX L. ; 2003 : Préjudices causés par les subventions aux filières cotonnières de l'AOC éd. CIRAD Louis Goureux consultation, Washington. Nov. - Fév. 2003 p. 60.

[7] AMEDE, L. S., 2002 : les agriculteurs africains doivent être soutenus comme ceux de l'UE et des USA. In Fraternité Matin, Abidjan, $1^{\text {er juillet } 2002 ; p 13 .}$

[8] TOURE AT and COMPAORE B (2004). Your farm subsidies are strangling us; in the New York Time, New York, July 11, 2003.

[9] WISE TA 2004. The paradox of agricultural subsidies: measurement issues, agriculture dumping, and policy reform. Edit. Global Development and Environment Institute. Tafts University, USA, Medford. Working paper. Nov. 04- 02 May 2004. p 33.

[10] MAGRIN G. 2002. Le sud du Tchad en mutations: des champs de coton à la sirène de l'or noir. Thèse de doctorat.

[11] MAHAMAT DJIMADINGAR et al, (2011), Présentation du Tchad. Actes du colloque sur les statistiques de l'environnement du 05-09 décembre 2001. Page 1-7

[12] CHRETOM B., $2000:$ La coton Tchad accuse un déficit de 40000000 à la production du coton. N'Djaména HEBDO n ${ }^{\circ}$ 449, 3pp.

[13] REOUNODJI F., 2002: Dynamiques agricoles dans les savanes du Tchad : quelles perspectives cotonnières? Actes du colloque, 27-31 mai 2002, Garoua, Cameroun.

[14] MBAIHOUNDAM P.; 1991: Le marché autogéré : fonctionnement et impacts socio-économiques au Tchad. Rapport de stage.- Ndjaména, Tchad. Université du Tchad.$41 \mathrm{p}$.

[15] BONNASSIEUX A., 2002: Filière coton, émergence des organisations de producteurs et transformations territoriales au Mali et au Burkina Faso. Les cahiers d'Outre-mer n ${ }^{\circ} 220$.

[16] BAIDOU R., 1993 : Groupements paysans, mains basses sur les ristournes. N'Djaména HEBDO n 108, 7-8pp. 